\title{
Mapping of rock resistivity value using geoelectrical method Schlumberger configuration in Solok Regency, West Sumatera
}

\author{
Elsi Ariani' ${ }^{1}$, Akmam $^{2}$ \\ ${ }^{1}$ Physics Department of State Islamic University Sultan Maulana Hasanuddin Banten, Jalan \\ Jenderal Sudirman No. 30 Serang, Banten \\ ${ }^{2}$ Physics Department of Padang State University, Jalan Prof. Dr. Hamka Air Tawar Padang, \\ West Sumatera \\ Email: ${ }^{1}$ elsi.ariani@uinbanten.ac.id. ${ }^{2}$ akmam_db@,fmipa.unp.ac.id
}

Received 4 February 2019, Revised 14 March 2019, Published 29 March 2019

\begin{abstract}
Mapping of rock resistivity value is useful for knowing the potential of the natural wealth contained in the earth. Investigation of resistivity value in Solok Regency is using 3 lines. The first line is at $\mathrm{S}$ $00055^{\prime} 0.7$ "and E 100040'56.8" coordinates, the second line is located at $\mathrm{S}$ 00054'53.2 "and E 100041'00.9" coordinates, and the third line is coordinated by S $00055^{\prime} 20.5$ "and E 100041'01.8". The method of mapping is using the Geoelectric method with Schlumberger Configuration and the Ares (Apparent Resistivity) tool. The data obtained is processed by using Res2Dinv software to be analyzed and interpreted. The results obtained on the first line have resistivity value of 3.95-641 $\Omega \mathrm{m}$ which is interpreted by having a rock structure consisting of Groundwater, Clay, Dry Clay, Basalt and Andesite. Next on the second line, the resistivity values of 2.53-1560.5 $\Omega \mathrm{m}$ are obtained consisting of layers of rock Groundwater, Clay, Dry Clay, Basalt, and Andesite. Finally on the third line have resistivity value about 6.85-113.5 $\Omega \mathrm{m}$ having a Groundwater, Tuff, Sandstone, Clay, Dry Clay, Basalt, Andesite, and Lava rock structure. The Tuff rock layer is estimated as a geothermal reservoir because its resistivity value is $20.8-23.6 \Omega \mathrm{m}$ surrounded by more contrasting rock layers and is located between two solid rock layers.
\end{abstract}

Keywords: resistivity, geoelectrical method, Schlumberger Configuration

\section{Introduction}

The mapping of rock resistivity is the first step to know the rock structure in an area. The mapping is purpose to get information about the potential wealth of natural resources. Solok Regency is one of regency in West Sumatera and has not been known the rock structure, so that it can't be done the exploration of its natural resources. On the early survey the hot spring is founded on Lembang Jaya Distric. The Solok Regency that is indicated to have geothermal source energy. According to the local community, hot springs come from Talang Mountain. The mountain is still active and it is estimated 
to have geothermal energy resource. Conceptually, the geothermal model can be seen on Figure 1.

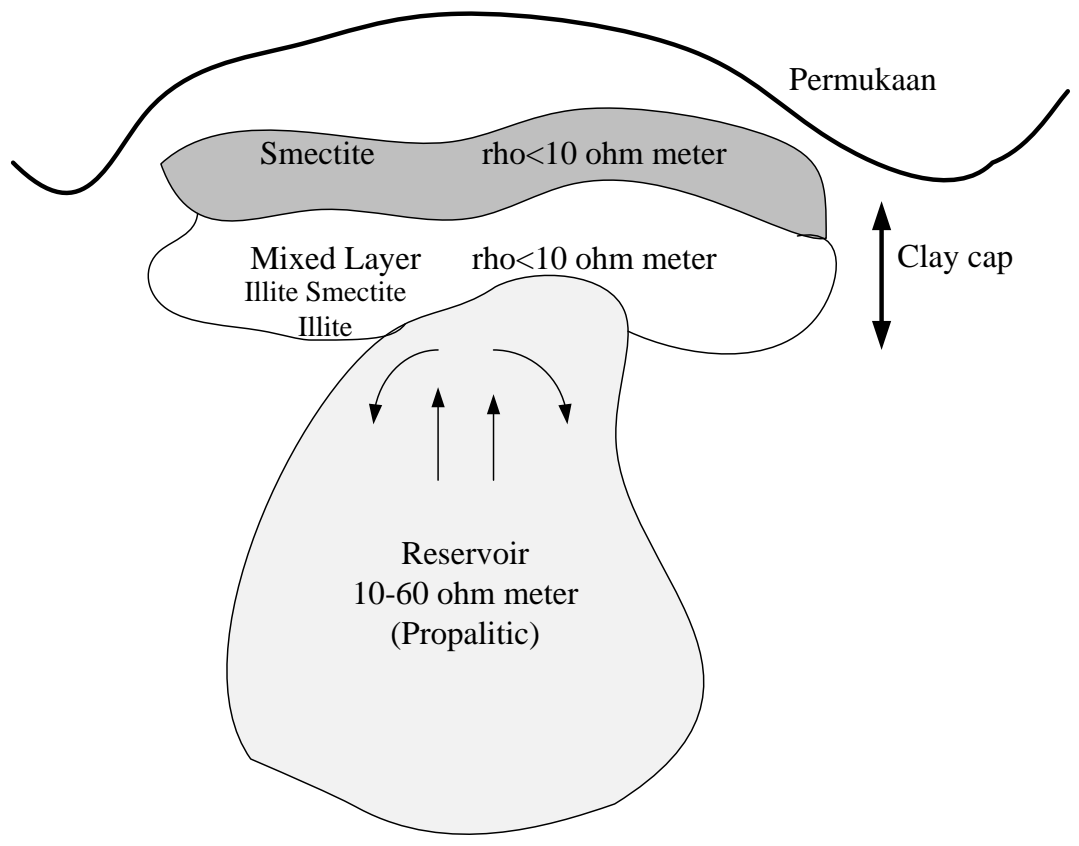

Figure 1. Conceptual model of geothermal (E.Ariani and W. Srigutomo, 2016)

The Figure 1 describe the formation of geothermal. The overburden layer has high resistivity value. Then, underneath is followed by smectite layer has low resistivity value $<10 \Omega \mathrm{m}$. Next, illite smectite layer or mixed layer has low resistivity value 10 $\Omega \mathrm{m}$. There layer is called by clay cap and there is propylitic alteration layer under the clay cap that is geothermal reservoir layer. The layer has resistivity value about 10-60 $\Omega \mathrm{m}$ (Pellerin, 1996).

Eysteinsson on his research said that the resistivity geothermal value in out active volcanic area is about 1-5 $\Omega \mathrm{m}$ (Eysteinsson, 1994). Haerudin is also said that the potential rocks as geothermal source were volcanic and Tufan stone. They have 24-62.2 $\Omega \mathrm{m}$ resistivity value and depth of $20 \mathrm{~m}$ (Haerudin, 2008). Talang Mountain has volcanic and Tuf stone, so that is estimated to have geothermal energy and another mineral.

\section{Research Methods}

Geoelectrical method is one of geophysics method to describe subsurface layer (M.H.Z. Abidin et al, 2010). Using this method, we can learn resistivity variation laterally and vertically (Tsepav, Mattew Tersoo, and Umar Mohammed Alhahi, 2016). This method utilize electricity of stone (Santoso, 2002). Every layers can be predicted its depth and thickness in subsurfaces. So, it will make easy to interprete this layer (A. Octova, A.S. Muji, M. Raeis, dan R.R Putra, 2019). Some scientist was using this method to investigate groundwater (G.R. Lashkaripour, 2003), and to explore geothermal reservoir distribution (Rahmi Hidayati, Sesri Santurima, Akmam, 2011). The work principle geoelectrical method is by doing injection an electric current inject to earth (Uros Stepisnik, 2008). 
This research was using Schlumberger configuration. It is because the method could do far current penetration and could describe resistivity distribution model simply (Ugwu et al, 2016). This method was using 2 current electrode and 2 potential electrode with space potential electrode smaller than current electrode.

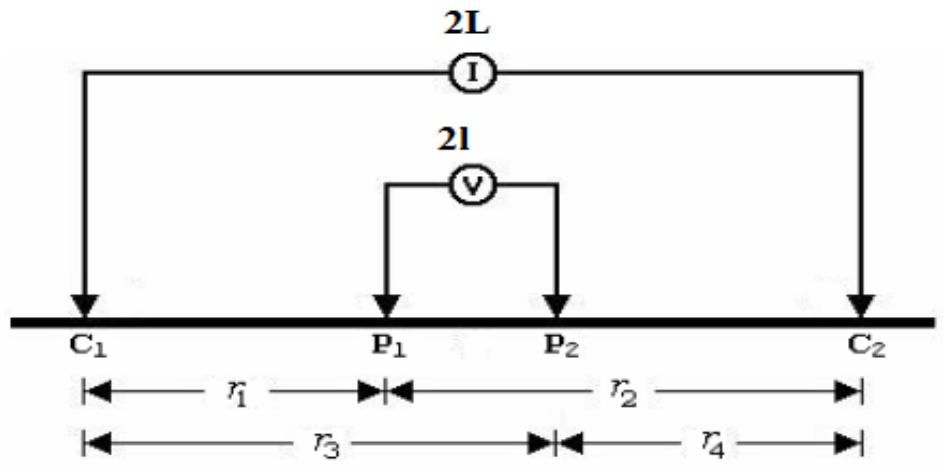

Figure 2. Schlumberger configuration (Teti, 2008)

Apparent resistivity value is determined by equation:

$$
\rho_{a}=\frac{\Delta V}{I} K
$$

With $\mathrm{K}$ is geometry factor that has value:

$$
K=\left[\left(\frac{1}{r_{1}}-\frac{1}{r_{2}}\right)-\left(\frac{1}{r_{3}}-\frac{1}{r_{4}}\right)\right]^{-1}
$$

\subsection{Location}

Lembang Jaya District, Solok Regency is a place for getting data. Survey use 3 lines. Based on geological map of Solok Regency, this area is compossed by Andesit, Basalt, Breccia, and it is estimated to have energy resource. Then Sediment and Malihan as Gamping, Sabak, and Filit stone are estimated to have mineral resource potential. 


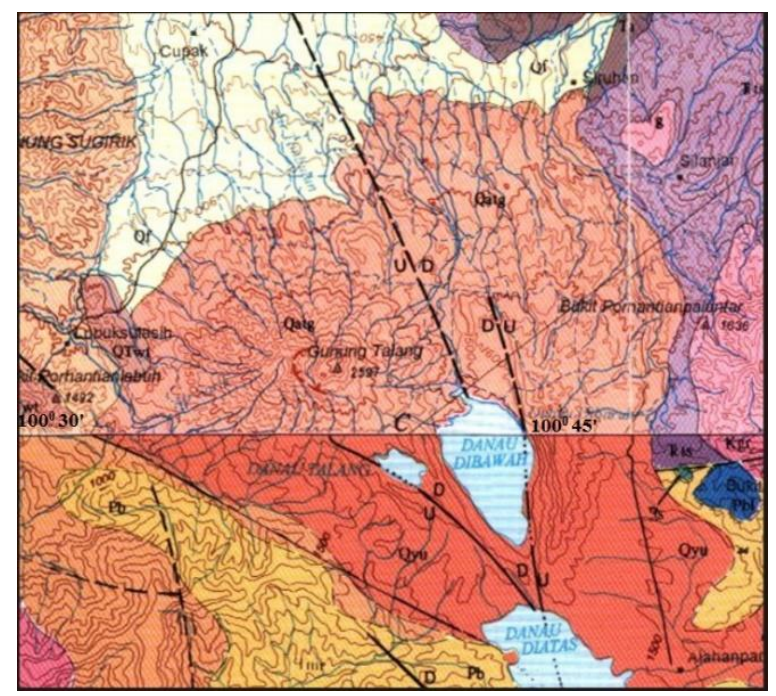

Figure 3. Geological map of Solok Regency (Kastowo, 1995)

Based on the Figure 3 the area is in around Talang Mountain is arranged Qatg stones that consist of Breccia stone, lava deposits, and Lapili that is included on Basalt and Andesite. The Basalt has resistivity value about $10-1.3 \times 10^{7} \Omega \mathrm{m}$, while the Andesite has resistivity value about $4.5 \times 10^{4}-1.7 \times 10^{2} \Omega \mathrm{m}$ (Telford, 2004). Another stone is Qtwt that fused Tuf, Qtau is volcanic, Ta is Andesite and Basalt, ect (Kastowo, 1995).

\subsection{Tolls}

Apparent Resistivity (Ares) was used to this research. It worked automatically and reached up to $155 \mathrm{~m}$. Meanwhile manually, it could be used up to unlimited depend on ours cable. Principle of Ares took a data and saved automatically. Then data could be downloaded and was done to process by using Res2DInv software. The result gave the different colour on resistivity value. The last did to compare to geological map and get to image in each layer in subsurface.

\section{Results}

The research has been carried out by collecting data current, potential, apparent resitivity and standard deviation to each lines. The first line had length $155 \mathrm{~m}$. The distribution of resistivity value was about 3.95- $641 \Omega \mathrm{m}$. The depth was until 33.1 meter. 


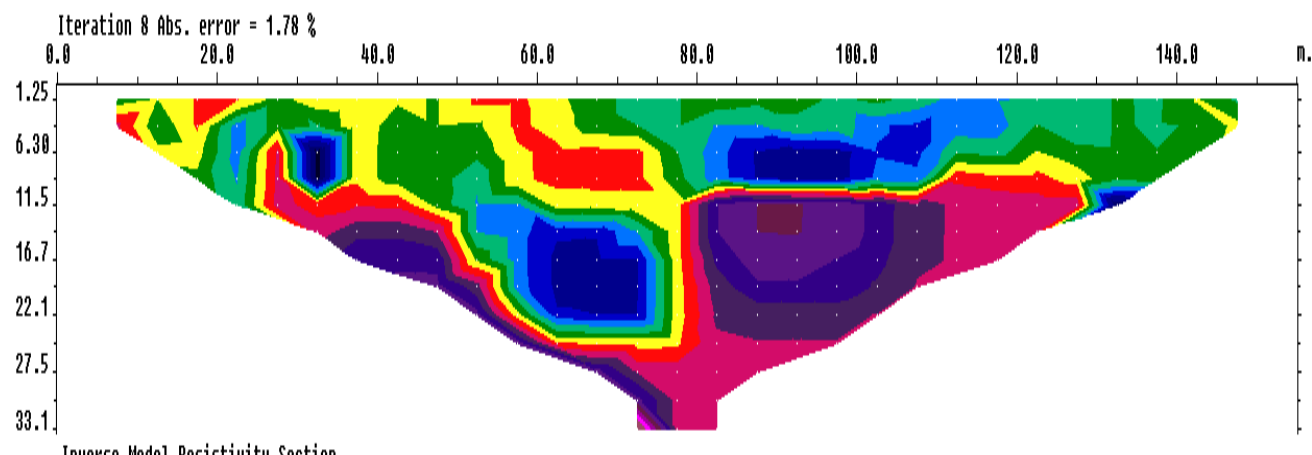

Inverse Model Resistivity Section

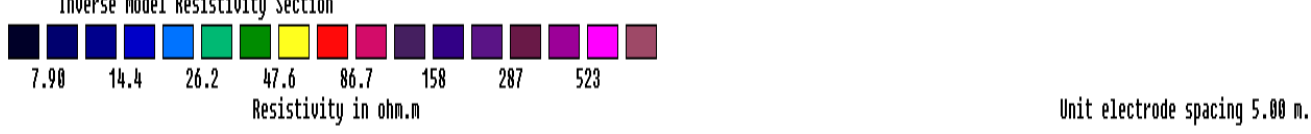

Figure 4. Distribution resistivity value section one

Based on Fig 4, we can make to category with colour and see Table 1:

Table 1. Apparent resistivity value, depth, thicknes, and rock type

\begin{tabular}{|c|c|c|c|c|}
\hline Colour & Resistivity Value & Depth & Thickness & Rock Type \\
\hline & $<26,2 \Omega \mathrm{m}$ & $\begin{array}{l}1,25-8,9 \mathrm{~m} \\
3,78-10,2 \mathrm{~m} \\
11,5-24,8 \mathrm{~m}\end{array}$ & $\begin{array}{l}7,65 \mathrm{~m} \\
6,42 \mathrm{~m} \\
13,3 \mathrm{~m}\end{array}$ & Groundwater \\
\hline & $26,2-67,15 \Omega \mathrm{m}$ & \multicolumn{2}{|c|}{ Spread } & Clay \\
\hline & $67,15-86,7 \Omega \mathrm{m}$ & \multicolumn{2}{|c|}{ Spread } & Dry clay \\
\hline & $86,7-276 \Omega \mathrm{m}$ & $11,5-24,8 \mathrm{~m}$ & $13,3 \mathrm{~m}$ & Basalt \\
\hline & $276-641 \Omega \mathrm{m}$ & $30,3-33,1 \mathrm{~m}$ & $2,8 \mathrm{~m}$ & Andesite \\
\hline
\end{tabular}

The resulted analyse and interprete from the section one is having the rock structure such as (1)The Groundwater has resistivity value about $<26.2 \Omega \mathrm{m}$ at depth 1.25 meter until 24.8 meter with varies of thicknesses 6.42 meter until 13.3 meter, (2) The Clay has resistivity value 26.2- $67.15 \Omega \mathrm{m}$ with spread position, (3) The Dry Clay has resistivity value $67.15-86 \Omega \mathrm{m}$ with spread position too, (4) The Basalt has resistivity value about 86.7- $276 \Omega \mathrm{m}$ at depth 11.5- 24.8 meter with thicknesses 13.3 meter, (5) The Andesite has resistivity value 276- $641 \Omega \mathrm{m}$ at depth 30.3 until 33.1 meter with thicknesses 2.8 meter.

Then, section two has length $440 \mathrm{~m}$ and depth 78.7 meter with resistivity value range 24.3- $1560.5 \Omega \mathrm{m}$. 


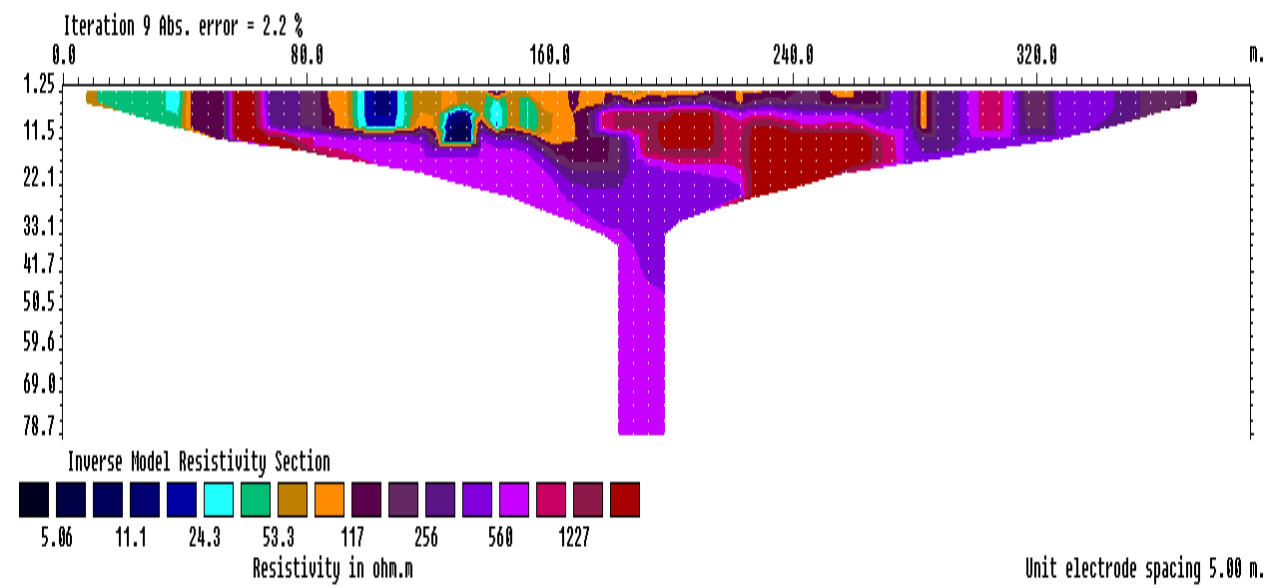

Figure 5. Distribution resistivity value section two

The grouping of type rock for section two:

Table 2. Resistivity value, depth, thickness, and type of rock to section two

\begin{tabular}{|c|c|c|c|c|}
\hline Colour & Resistivity Value & Depth & Thickness & Rock Type \\
\hline & $<24.3 \Omega \mathrm{m}$ & $\begin{array}{l}1.25-8.93 \\
\text { meter }\end{array}$ & $\begin{array}{l}7.68 \\
\text { meter }\end{array}$ & Groundwater \\
\hline & 24.3-53.3 $\Omega \mathrm{m}$ & \multicolumn{2}{|c|}{ Spread } & Clay \\
\hline & $53.3-58.5 \Omega \mathrm{m}$ & \multicolumn{2}{|c|}{ Spread } & Dry Clay \\
\hline & $58.5-280 \Omega \mathrm{m}$ & \multicolumn{2}{|c|}{ Spread } & Basalt \\
\hline & $280-1560.5 \Omega \mathrm{m}$ & $\begin{array}{l}6.37-78.7 \mathrm{~m} \\
\text { and spread }\end{array}$ & $21.23 \mathrm{~m}$ & Andesite \\
\hline
\end{tabular}

Based on the Table 2, we could estimated the rock type are (1) The Groundwater has resistivity value about $<24.3 \Omega \mathrm{m}$ with depth $1.25-8.93$ meter and thicknesses 7.98 meter, (2) The Clay has resistivity value 24.3- 53.3 $\Omega \mathrm{m}$ spread along the surface, (3) The Dry Clay has resistivity value 53.3- 58.5 $\Omega \mathrm{m}$ and spread along surface too, (4) The Basalt has resistivity value about 58.5 -280 $\Omega \mathrm{m}$ and spread in some point in layer, (5) The Andesite has resistivity value 280-1560.5 $\Omega \mathrm{m}$ and spread until the depth 78.7 meter.

The last section, data has been taken automatically and manually with length 550 meter and the depth until 109.5 meter. The variation of resistivity value is about 20.8$113.5 \Omega \mathrm{m}$. The Figure 6 is the section three: 


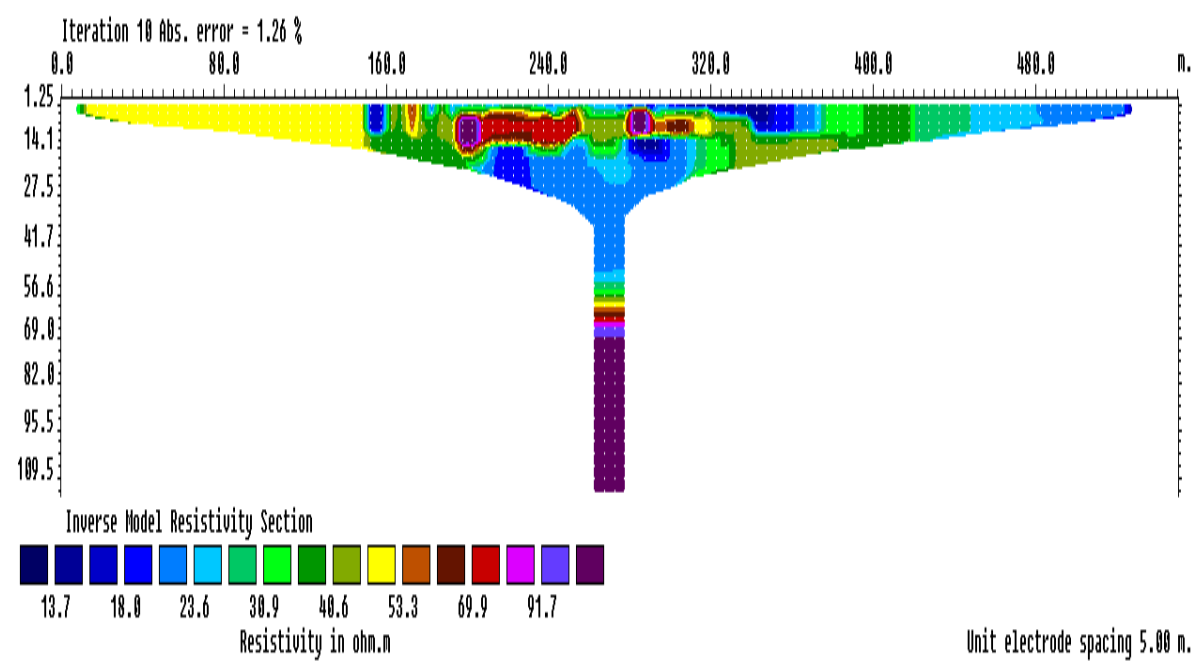

Figure 6. Distribution resistivity value section three

Based on the colour resistivity value, we can make some category for rock type:

Table 3. Resistivity value, depth, thickness, and type of rock the section three

\begin{tabular}{|c|c|c|c|c|}
\hline Colour & Resistivity Value & Depth & Thickness & Rock Type \\
\hline & $<20,8 \Omega \mathrm{m}$ & $\begin{array}{c}1,25-8,9 \\
\text { meter }\end{array}$ & 7,65 meter & Groundwater \\
\hline & $20,8-23,6 \Omega \mathrm{m}$ & $\begin{array}{c}8,9-50,64 \\
\text { meter }\end{array}$ & 41,74 meter & Tuff \\
\hline & $23,6-27,25 \Omega \mathrm{m}$ & $\begin{array}{c}8,5-53,62 \\
\text { meter }\end{array}$ & 45,12 & Sandstone \\
\hline & $27,25-53,3 \Omega \mathrm{m}$ & $\begin{array}{c}53,62-56,6 \\
\text { meter dan } \\
\text { menyebar }\end{array}$ & 2,98 meter & Clay \\
\hline & $53,3-80,8 \Omega \mathrm{m}$ & $\begin{array}{c}56,6-59,08 \\
\text { meter }\end{array}$ & 2,48 meter & Dry Clay \\
\hline & $80,8-91,7 \Omega \mathrm{m}$ & $\begin{array}{c}59,08- \\
64,04 \text { meter }\end{array}$ & 4,96 meter & Basalt \\
\hline & $91,7-102,6 \Omega \mathrm{m}$ & $\begin{array}{c}\text { 64,04-69 } \\
\text { meter }\end{array}$ & 4,96 meter & Andesite \\
\hline & $102,6-113,5 \Omega \mathrm{m}$ & $\begin{array}{c}69-109,5 \\
\text { meter }\end{array}$ & 40,5 meter & Lava \\
\hline
\end{tabular}

The section three is estimated to have of rock type are (1) The Groundwater has resistivity value $<20.8 \Omega \mathrm{m}$ at the depth $1.25-8.9$ meter with thicknesses 7.65 meter, (2) The Tuff has resistivity value 20.8- 23.6 $\Omega \mathrm{m}$ at the depth 8.9- 50.04 meter and thicknesses 41.74 meter, (3) The Sandstone has resistivity value 23.6- 27.25 $\Omega \mathrm{m}$ at the 
depth 8.5- 53.62 meter and thicknesses 45.12 meter, (4) The Dry Clay has resistivity value 53.3- 80.8 $\Omega \mathrm{m}$ at the depth 56.6- 59.08 meter and thicknesses 2.48 meter, (5) The Basalt has resistivity value $80.8-91.7 \Omega \mathrm{m}$ the location is 59.08-64.04 meter and thicknesses 4.96 meter, (6) The Andesit has resistivity value about 91.7- $102.6 \Omega \mathrm{m}$ at the depth 64.04- 69 meter and thicknesses 4.96 meter, (7) The Lava stone has resistivity value 102.6- $113.5 \Omega \mathrm{m}$ at the depth 69-109.5 meter dan thicknesses 40.5 meter.

The Tuff layer is estimated as geothermal reservoir source because it is located between the two the solid rock that are Basalt and Andesite. The founded support by Onodera's research that geothermal reservoir rock has resistivity value 20-70 $\Omega \mathrm{m}$ (Mardiana, 2007) and based on Haerudin's research resistivity geothermal value is about 24- 62.2 $\Omega \mathrm{m}$ at the depth $>20$ meter (Haerudin, 2008)

\section{Conclusion}

Based on the results, we can make conclusion that the first line have the rock structure Groundwater, Clay Cap, Dry Clay, Basalt and Andesite, the second line have Groundwater, Clay, Dry Clay, Basalt, Andesite, and the third line have variation resistivity value with the rock type are Groundwater, Tuff, Sandstone, Clay, Dry Clay, Basalt, Andesite, and Lava. The Tuff stone is estimated as geothermal reservoir rock with resistivity value $20.8-23.6 \Omega \mathrm{m}$. It is located between two of rock solid.

\section{Acknowledgements}

The authors wish to thank Indonesian Ministry of Research, Technology, and Higher Education (Ristekdikti) for funding the research.

\section{References}

A. Octova, A.S. Muji, M. Raeis, and RR Putra.'Identification of Aquifer using Geoelectrical Resistivity Method with Schlumberger Array in Koto Panjang Area, Nagari Tigo Jangko, Lintau Buo Sub-District, Tanah Datar Regency”. J.Phys. Conf. Ser., 1185, 012009, 2019.

E. Ariani and W. Srigutomo. “1D and 2D Occam's Inversion of Magnetotelluric Data Applied in Volcano Geothermal Area in Central Java, Indonesia”. J.Phys. Conf. Ser.,739,012036, 2016.

Eysteinsson, H., Knutur., A., dan Olafur, GF. "Resistivity Methods in Geothermal Prospecting in Iceland”. Surveys in Geophysics. No 15 page 263- 275, 1994.

G.R. Lashkaripour. "An Investigation of Groundwater Condition by Geoelectrical Resistivity Method: A Case Study in Korin Aquifer, Southest Iran". Journal of Spatial Hydrology. Vol 3, No.1 Fall 2003.

Gustam, Lubis. "Exploration of Groundwater Potential with Geoelectric Resistivity Method in Tanjung Kuba, Batu Bara Regency". IOSR Journal of Applied Geology and Geophysics Vol 5 Issue 1 Ver. II PP. 71-73. 2017.

Haerudin, N, Syamsurizal, R., and Eva Y. "Geoelectrical Method for Geothermal Fluid 
Spread scheme determine in Prospect Area Geothermal Rajabasa Kalianda Mountain South Lampung". Proceeding of National Seminar Sains and Technology II, 2008. University of Lampung.

Kastowo. "Map of Geology Solok Regency, West Sumatera. Padang: Mining Service West Sumatera.

Loke, M.H. " Electrical Imaging Survey for Environmental and Engineering Studies, a Practical Guide to 2D and 3D Surveys". 5, Cangkat Minden Lorong 6, Minden Height, 11700 Penang, Malaysia, 2004.

M. H.Z Abidin, et al. "Application of Geoelectrical Method in Subsurface Profile Forensic Study". Proceeding of MUCET2010. Malaysian Universities Conference on Engineering and Technology, 2010.

Onodera, S. "Research Report" in Mardiana. Manifestation of Geothermal Based on Resistivity Value. UNPAD, 2007.

Pellerin, Johston, J.M Wohmann, GW. "A numerical Evaluation of Electromagnetic Methods in Geothermal Exploration". Geophysics, Vol 61 No 1 P 121-130, 14 Figs, 1996.

Rahmi, H., Sesri, S., and Akmam. "Investigation of Vormi Spread with Geoelctrical Method as Alternative countermeasure of Energy Crisis in Solok Regency". Proceeding of National Seminar HFI Sub West Sumatera ISBN 978-602-19060-3, 2011.

Telford, W.MGeldart., L.P., and Sheriff R.E. Applied Geophysics Second Edition Digital. USA: Cambridge Uniersity, 2004.

Teti, Zubaidah and Kanata, Bulkis. Modelling of application Physics Geoelectrical Method Sclumberger Method for investigation Groundwater Location. Mataram: Universitas Matara,, 2008.

Tsepav, Matthew Tersoo, and Umar Mohammed Alhaji. "Evaluation of Aquifer Protective Capacity and Soil Coorosivity Using Geoelectrical Method". World Engineering and Applied Science Journal 7(3): 135-144, 2016.

Ugwu, et al. "Application of Geoelectrical Resistivity Method to the Assesment of Groundwater Pollution: A case Study of Onibu Eja Active Open Dumpsite, Osogbo, Soutwestern Nigeria". International Journal of Environmental Protection, Vol.6 Iss.1, PP. 160-174, 2016

Uros, Stepisnik. The Application of Electrical Resistivity Imaging in Collapse Doline Floors: Divaca Karst, Slovenia. Studia Geomorphologica Carpatho Balcanica Vol. XIJI: 41-51, 2008. 